\title{
CHILD HEALTH CARE IN BRAZIL: ASPECTS OF PROGRAM VULNERABILITY AND HUMAN RIGHTS
}

Glória Lúcia Alves Figueiredo ${ }^{1}$

Débora Falleiros de Mello

Figueiredo GLA, Mello DF. Child health care in Brazil: aspects of program vulnerability and human rights. Rev Latino-am Enfermagem 2007 novembro-dezembro; 15(6):1171-6.

This study aimed to examine the epidemiological approach in Brazilian child health programs, towards the reflection on current guidelines from the perspective of program vulnerability and human rights. A descriptive study was carried out, based on the analysis of official documents elaborated by the Brazilian Ministry of Health. The expansion and reorganization of family health practices and integrated care for prevailing childhood diseases are aimed at promoting health and quality of life to children and families. Health professionals, imbued with observation and intervention, can be considered agents to respect, protect and implement human rights.

DESCRIPTORS: child; vulnerability; human rights

\section{ATENCIÓN A LA SALUD DEL NIÑO EN BRASIL: ASPECTOS DE LA VULNERABILIDAD PROGRAMÁTICA Y DE LOS DERECHOS HUMANOS}

La finalidad de este estudio es investigar la aproximación epidemiológica en los programas de salud del niño en Brasil, con vistas a la reflexión de las directivas actuales en la perspectiva de la vulnerabilidad programática y de los derechos humanos. Realizamos un estudio descriptivo, basado en el análisis de documentos oficiales elaborados por el Ministerio de la Salud, en Brasil. Verificamos que los objetivos de la amplificación y reorganización de las prácticas de salud de la familia y de la atención integrada a las enfermedades prevalecientes en la infancia son las de promover la salud y cualidad de vida de niños y familias. Los profesionales deben ser agentes públicos imbuidos de observación e intervención para respetar, proteger y efectuar derechos humanos.

DESCRIPTORES: niño; vulnerabilidad; derechos humanos

\section{ATENÇÃO À SAÚDE DA CRIANÇA NO BRASIL: ASPECTOS DA VULNERABILIDADE PROGRAMÁTICA E DOS DIREITOS HUMANOS}

Este estudo tem como objetivo examinar a abordagem epidemiológica nos programas brasileiros de saúde da criança, com vistas à reflexão das atuais diretrizes na perspectiva da vulnerabilidade e dos direitos humanos. Trata-se de estudo descritivo, alicerçado na análise de documentos oficiais veiculados pelo Ministério da Saúde, Brasil. Verificou-se que a ampliação e reorganização das práticas de saúde da família e da atenção integrada às doenças prevalentes na infância preconizam a promoção da saúde e qualidade de vida de crianças e famílias. Os profissionais de saúde, imbuídos de observação e intervenção, podem ser considerados agentes para respeitar, proteger e efetivar direitos humanos.

DESCRITORES: criança; vulnerabilidade; direitos humanos

${ }^{1}$ RN, Doctoral student; ${ }^{2}$ PhD Professor, e-mail: defmello@eerp.usp.br. University of São Paulo at Ribeirão Preto, College of Nursing, WHO Collaborating Center for Nursing Research Development, Brazil 


\section{INTRODUCTION}

Child health care in Brazil has been changing. Over time, it has been influenced by a range of factors: the historical period, advancements in technicalscientific knowledge, guidelines of social policies and the involvement of different social agents and segments.

Epidemiology has shown that a population's differential health and disease characteristics are essential for research in any society ${ }^{(1-3)}$. In maternalchild health, epidemiological studies frequently address perinatal and neonatal health, which shows there is an association between the health-disease process, sanitation, nutrition, income, medical care, among others, and that these aspects are mutually correlated. The availability of food, housing quality and access to essential services like sanitation and health care are considered to be dependent on the families' purchasing power. Moreover, how the family uses its income and public services depends on the family members' education level, particularly the mother's ${ }^{(4)}$.

Modern epidemiology is based on the concept of risk. Focusing on risk is considered an important approach for primary health care, mainly to establish health service priorities and estimate health promotion and preventive care needs. Using the risk focus in maternal-child health is associated with the idea that mothers and children are more susceptible and more likely to be affected by changes in their health ${ }^{(5)}$

Considering health care and the role of the State, the latter has been confronted with the challenge to reconstruct health care models that are capable of detecting medium and long-term needs, thus ensuring a more equitable and righteous development ${ }^{(6)}$. The rules and actions implemented by the State are the social policies, which include health policies, put in practice through programs and services offered to population groups.

The political rules that take the form of health programs give rise to important questions about health needs, vulnerabilities, citizenship and human rights. Thus, this study aims to present aspects of the epidemiological approach in Brazilian child health programs, with a view to reflecting on current guidelines from the perspective of program vulnerability and human rights.

\section{EPIDEMIOLOGICAL APPROACH IN PUBLIC POLICY GUIDELINES FOR CHILD HEALTH CARE IN BRAZIL}

To examine the current public policy guidelines for child health care in Brazil, this study reviews some aspects and principles of the Brazilian health system, constructed over the past 25 years.

In the 1970's and 1980's, maternal-child health programs were characterized as vertical, because their goals and standards were decided on at the central level and by technical criteria, in line with the technocratic administration model adopted in Brazil at that time ${ }^{(7)}$.

In the 1980's, based on the analysis of the Brazilian population's sanitary and epidemiological conditions, the Integral Child Health Program (ICHP) was created. The central goal was to ensure integral care to children's health through basic actions, representing the health sector's response to the most frequent and important problems in the mortality of children aged 0 to $5^{(8)}$. Focused on integral child health care, five basic actions were proposed: promoting breastfeeding and food advice in the first year of life, controlling diarrhea, controlling respiratory diseases in childhood, immunization, and follow-up of growth and development as a method to organize care in this age range.

In this program, the epidemiological approach was associated with the explanation of the malnutrition-infection binomial in the structure of child morbidity and mortality structure, which was very complex, as well as the definition of its multiple determining factors. It was considered that there was a long and ramified chain of factors that could precede the high prevalence rates of malnutrition and infection, and that all paths would lead to the adverse living conditions a large part of the child population grew up and developed in.

Health programs in the 1970's and 1980's displayed bias, as well as a mistaken range and interpretation of primary health care and health education concepts $^{(7)}$, generating operational difficulties and a health care model that did not always correspond to the population's living conditions.

In the 1990's, the Family theme was revalued in the health sector, culminating with the creation of the Family Health Program (FHP) in 1994. In the attempt to reorganize primary health care, the Health Ministry took up the challenge of the family health 
strategy, based on the principles of care universality, equity and integrality ${ }^{(9)}$. The FHP has revealed to be an appropriate field to implement the Integrated Management of Childhood Illness (IMCI) strategy. This strategy, adopted in Brazil in 1996, as proposed by the World Health Organization and the United Nation Children's Fund, aims to: reduce the mortality of children under 5 years old; reduce the incidence/ severity of infectious diseases, especially pneumonia, diarrhea, intestinal parasites, meningitis, tuberculosis, malaria, measles and nutritional disorders; ensure adequate health care quality for children under 5 years old, in health care services as well as at home and in the community; strengthen health promotion and preventive actions in childhood ${ }^{(10-11)}$.

The epidemiological approach in this strategy is related to the country's child health profile, highlighting a proportion of deaths due to neonatal problems, which are considered difficult to intervene in, and, on the other hand, living with high morbidity rates due to the so-called underdevelopment diseases, such as pneumonia, diarrhea, malnutrition, and, especially in the North, malaria.

In primary health care, the Health Ministry launched, in 2002, the book Primary Health Care for Children: following children's growth and development. The document discusses the adoption of measures for healthy growth and development, focusing on guaranteeing the population's rights and complying with the State's responsibility ${ }^{(12)}$. These measures do not annul, but rather integrate those recommended by the IMCI strategy. The policy guidelines reaffirm that child growth and development are the reference for all child and adolescent care activities in biological, affective, psychological and social terms. The growth and development follow-up standards were gradually incorporated into the activities of the Community Health Agent Program (CHAP) and the $\mathrm{FHP}^{(12)}$.

This document's epidemiological approach is related to the identification of one or more risk factors, such as: low birth weight, low maternal education, extreme maternal ages (<19 years and >35 years), twinning, short interval between pregnancies (less than two years), unwanted child, early weaning, mortality of children under 5 years old in the family, inadequate housing conditions, low income, loss of family structure. All of these factors are considered as conditions that require health surveillance, with systematic child growth follow-up, due to the increased probability of perinatal and childhood diseases. Moreover, there is greater emphasis in terms of child development assessment and follow-up, identifying risk factors from an organic point of view, as well as in terms of family-related aspects.

In 2004, the Health Ministry launched an Agenda of Commitments for Integral Child Health and Reduction of Child Mortality ${ }^{(13)}$. In this document, child health care is included among the essential actions by the Health Ministry, with emphasis on integral and multiprofessional care that manages to understand the needs and rights of the child as an individual, emphasizing the responsibility to provide qualified and humanized health care. Child mortality is appointed as a major challenge for the country. The document outlines the following guiding principles of child health care: planning and developing intersectorial actions; universal access; welcoming; accountability; integral care; problem-solving care; equity; team work; developing collective actions, with an emphasis on health promotion actions; family participation; social control in local management; and permanent and systemized assessment of the delivered care.

Throughout the changes made in these guidelines, it was acknowledged that, despite advances, health indicators show that there is still a long road ahead to achieve the integral health rights assumed in Brazilian legislation.

\section{CHILD HEALTH PROGRAMS, PROGRAM VULNERABILITY AND HUMAN RIGHTS}

Considering these child health programs, and focusing, specifically, on the current situation, this essay attempts to apprehend the aspects of program and social vulnerability, and to appoint human rights issues.

Vulnerability is a relatively recent notion and treated as a major contribution to the renovation of health practices in general, and health promotion and prevention in particular. It originates in Law, through Universal Human Rights, directed at groups or individuals who are weakened in terms of civil rights. In the health area, it has been primarily studied in HIV/AIDS epidemic research, with discussions and answers to the need to advance beyond the approach of risk reduction strategies ${ }^{(14)}$.

In terms of program vulnerability, it should be highlighted that it is associated with the following 
aspects: stating the commitment, transforming commitment into action, developing coalition, planning and coordination, managing, responding to treatment and prevention needs, obtaining financial resources, sustaining efforts, evaluating progress and impact $^{(15)}$.

What the expression of commitment is concerned, the government has made efforts to create and sustain child health care programs since the 1970 's. In the 1990's, the need to change the health care model was acknowledged, assuming the commitment to restructure primary health care. In addition, initiatives were taken to change commitment into action. Measures were adopted and incorporated into child care, adjusting the technical-administrative structure, establishing technical standards, defining operational tools and promoting human resource training and health education.

Developing coalition is observed when the documents express, as from the 1970's, an interconnection with the country's global development strategy, with a policy of expansion and consolidation of the basic service network, whose priority activities were characterized by the resolution of specific health problems, low cost and appropriate technological complexity to deliver services at the different levels. Institutional integration contributed to the implementation of integrated health actions, supporting, in the state sphere, state and regional health commissions. Intersectoriality in health and between social sectors has also been emphasized.

In terms of planning and coordination, all programs under study define objectives and strategies. In terms of management and obtaining financial resources, actions are proposed with a view to adjusting the services offered, their concentration and resource prioritization, dimensioned to solve the most urgent and prevailing health problems in the population of children under 5 years old.

In terms of meeting prevention and treatment needs, the set of actions aims at integral care delivery by health services, moving the focus from a diseasebased care to a care model that perceives children in their growth and development process, besides proposing the guarantee to extend primary health care coverage and, simultaneously, increase the problemsolving capacity. The previous approach emphasized the individual control of diseases and, nowadays, moves to the integrated care of treating and preventing prevalent childhood diseases. The notion of child development is expanded, considering children's and families' quality of life and well-being.

In terms of sustaining the effort, the government has made efforts to offer guarantees and strategies to continue the FHP and IMCI programs, with emphasis on following child growth and development. The adaptation of the IMCI strategy to meet the needs of the country's different regions, training of health workers, incentives to incorporate IMCI in undergraduate courses, strengthening community participation in child care, achieving broader care access in primary child health care services and increasing the number of family health teams have been important measures.

Regarding the evaluation of progress and impact, these specifications are not thoroughly detailed. In terms of evaluation, studies have been performed outside the program. The notion of evaluation should start when the activity is established, a guiding horizon, which is elaborated into detailed criteria and methods, with sufficient flexibility to absorb the development dynamics of the project, thus transforming itself when needed ${ }^{(16)}$. The rationality of an intervention project should be expressed by clearly defined and objectively verifiable means and ends. Hence, an evaluation protocol should be able to express and constantly give feedback to this rationality. Objectives, goals, strategies and some evaluation criteria like economic rationality, mainly efficacy in general, as well as other closed results were found when elaborating the programs evaluated in this study. However, the result assessment of program action was not feasible from the start, which made it impossible to give feedback to the program rationalities, offer better quality interventions and guaranteeing a solid evaluation process, that is, realistic, productive and operational ${ }^{(16)}$.

In terms of human rights, social rights are present in the political guidelines of child health care. Social rights are fundamental civil rights, called positive or second-generation, and include the rights to education, work and health, presupposing concrete initiatives by the State to ensure them ${ }^{(17)}$.

In Brazil, the right to health gained strength in the last decades of the $20^{\text {th }}$ century. Initially, in the early 1960's, the $3^{\text {rd }}$ National Health Conference defined everybody's right to health, and the discussions proposed municipalization as a way to implement it ${ }^{(18)}$. In the 1980 's, with the Sanitary Reform and Single Health System (SHS) proposals, 
health was highlighted as a right, with emphasis on the principles of universality, equity, integral actions and health promotion. The 1988 Constitution and the creation of the SHS again aroused discussions about health as a fundamental human right. In this process, the principles of Primary Health Care (PHC) were also highlighted, recovered and expanded in the 1990's. PHC ideas emphasize that primary health care is the first step in establishing the right to health and is directly associated with human rights, which imply equity, solidarity, intersectoriality, community participation, social control, universal access to health care and reorientation of the health care model. Health is reaffirmed as an inviolable, inalienable, inexorable, undividable and universal human right ${ }^{(18)}$.

Thus, child health programs are supported by policy guidelines that, to a certain extent, consider the right to health. Public health policies and programs can promote or violate human rights, posing difficult questions for researchers and health care professionals to reflect on ${ }^{(17)}$.

The guarantee to access, quality care, integral health care, preventive care and treatment schemes, postulated in health programs, exerts a positive effect of public health action on human rights. Children have rights that mainly concern public autonomy, i.e., social rights, such as the right to adequate growth and development, breastfeeding, nutrition, vaccination, hygiene, environmental sanitation, protection measures, accident prevention, access to education, health care, in other words, the right to life. Another important aspect is the guarantee that parents learn the basic health principles and receive support to apply that knowledge in child care, according to the 1989 Convention on the Rights of the Child ${ }^{(19)}$.

However, considering only children's exclusive rights can generate delicate and potentially harmful situations if one looks at parents and families merely in terms of accomplishing duties. This would lead to authoritarian development perspectives of public policies in health ${ }^{(17)}$. On the other hand, the documents studied here express a commitment not only to survival, but also to children's quality of life, perceiving them as a whole and in relation with their environment, parents and family.

According to the Convention on the Rights of the Child, the rights to life, survival, maximum development, access to health and health services should not be considered as children's and adolescents' needs only, but are also fundamental human rights. Moreover, protecting and complying with these fundamental rights depends on the practice of the following rights: non-discrimination; education and access to appropriate information; privacy; protection from all forms of violence; rest, leisure, and recreation; adequate life standard; no abuse; and participation, with the right to be heard ${ }^{(19)}$. The State, in agreement with international conventions, declarations and pacts, should respect, protect and implement its citizen's human rights. Therefore, it has the duty to elaborate accountability plans, in the attempt to avoid disrespecting, not protecting and not practicing a right.

The Statute of the Child and Adolescent (SCA) is one of the organized civil society's greatest achievements in the 1990's. The SCA managed to introduce significant changes in relation to the previous legislation, the so-called Code of Minors, instituted in 1979. Through the SCA, children and adolescents are considered citizens, with guaranteed personal and social rights, making public authorities implement public policies especially directed to this segment. On the other hand, this document also establishes the responsibility of society and parents in care for children and adolescents. The SCA is ruled by the doctrine of integral child and adolescent protection, created by the United Nations, which does not only apply to abandoned individuals and criminals. Putting this into practice is the Brazilian society's great challenge. The assessment of ten years of $\mathrm{SCA}^{(20)}$, in 2000, shows that the treatment offered to children and adolescents can be improved, with more involvement and responsibility by all segments, guaranteeing that they become citizens capable of building a just and democratic country.

\section{FINAL CONSIDERATIONS}

It is extremely important for health professionals to attempt to articulate political guidelines and health practice, seeking to expand them through research and by creating technologies that make it possible to reorganize family health practices and integral care to prevalent childhood diseases, thus promoting health and quality of life for children and families. These professionals should be public agents imbued with observation and intervention to respect, protect and practice human rights. 
In this sense, professional practice should be reconsidered, taking into consideration the importance of its transforming role, because it is expected that by transforming oneself and reality, after meeting people, health care spaces will be found. Nevertheless, countless

\section{REFERENCES}

1. Barros MBA. Saúde e classe social: um estudo sobre morbidade e consumo de medicamentos. [tese] Ribeirão Preto (SP): Faculdade de Medicina de Ribeirão Preto-USP; 1983.

2. Breilh J, Granda E, Campaña A, Betancourt O. Clase social y desigualdad ante la muerte en Quito. In: Breilh J, Granda E, Campaña A, Betancourt O. Ciudad y muerte infantil. Quito: CEAS; 1983.

3. Barbieri MA. Saúde materno-infantil e classe social: alguns aspectos do período perinatal da mãe e do recém-nascido. [tese]. Ribeirão Preto(SP): Faculdade de Medicina de Ribeirão Preto-USP; 1985

4. Monteiro CA, Freitas ICM. Evolução de condicionantes socioeconômicas da saúde na infância na cidade de São Paulo (1984-1996). Rev Saúde Pública 2002; 34(6):8-12.

5. Backett EM, Davies AM, Petros-Barvazian A. O enfoque de risco na assistência à saúde: com especial referência à saúde materno-infantil, inclusive planejamento familiar. Washington-DC: OPAS/OMS; 1985. Publicação Científica n0491.

6. Cohn A. Políticas sociais e pobreza no Brasil. Planejamento e Políticas Públicas, 1995; 2(12):1-18.

7. Tyrrel MARB. Programas nacionais de saúde maternoinfantil: impacto social e inserção da enfermagem. Rev Bras Enfermagem 1997;1(1):119-34.

8. Ministério da Saúde (BR). Assistência integral à saúde da criança: ações básicas. Brasília (DF): Ministério da Saúde; 1984.

9. Ministério da Saúde (BR). Saúde da família: uma estratégia para a reorientação do modelo assistencial. $2^{a}$ ed. Brasília (DF): Ministério da Saúde; 1998.

10. Ministério da Saúde [homepage na Internet]. Brasília: Ministério da Saúde; [Acesso em 2004 maio 31]. Atenção integrada às doenças prevalentes na infância: internações e custos proporcionais por grupos de patologias de crianças menores de 5 anos, SUS, Brasil [3 telas]. Disponível em: http://www.saude.gov.br/editora

11. Organização Pan-Americana da Saúde, Organização Mundial da Saúde. Melhorando a saúde das crianças. ICPCD: o enfoque integrado. Brasília (DF): OPAS/ICPCD; 2000.

12. Ministério da Saúde $(B R)$. Saúde da criança: acompanhamento do crescimento e desenvolvimento infantil. Cadernos de Atenção Básica, n.11, série A. Normas e Manuais Técnicos. Brasília (DF): Ministério da Saúde; 2002.

13. Ministério da Saúde (BR). Agenda de compromissos para a saúde integral da criança e redução da mortalidade infantil. Brasília (DF): Ministério da Saúde; 2004. difficulties remain in daily care, since many gaps persist and make it difficult to perform transformations, to execute a quality job, and to get to know and act on children's rights, specifically. It is in this context that the population learns how to use health services.

14. Ayres JRCM, França-Júnior I, Calazans GJ, Saletti-Filho HC. O conceito de vulnerabilidade e as práticas de saúde: novas perspectivas e desafios. In: Czeresnia D, Freitas CM, organizadores. Promoção da saúde: conceitos, reflexões, tendências. Rio de Janeiro (RJ): Ed.Fiocruz; 2003. p.11739.

15. Mann JM, Tarantola DJM, Netler TW (edts.). Aids in the world. Cambridge (ENG): Harvard University Press; 1992.

16. Ayres JRCM. O jovem que buscamos e o encontro que queremos ser (...). Série Idéias 1996; (29):15-24.

17. França-Júnior I, Ayres JRCM. Saúde pública e direitos humanos. In: Fortes PAC, Zoboli ELCP, organizadores. Bioética e saúde pública. São Paulo (SP): Edições Loyola/ Centro Universitário São Camilo; 2003. p.63-9.

18. Fundação Oswaldo Cruz. Saúde: um direito fundamental Radis-Comunicação em saúde 2003;5(13):16-8.

19. Unicef. World declaration on the survival, protection and development of children. New York: Unicef; 1990.

20. Secretaria de Assistência e Desenvolvimento Social (SP). Direitos da criança e do adolescente. São Paulo (SP): Secretaria de Assistência e Desenvolvimento Social; 2000. 